\title{
Prediction of the Viscosities of "Soda-Lime" Silica Glasses
}

\author{
Kenneth C. Lyon* \\ Institute for Materials Research, National Bureau of Standards, Washington, D.C. 20234
}

(March 6, 1974)

\begin{abstract}
Published data are used to develop factors for predicting the viscosity-temperature relationship from the compositions of "soda-lime" type silicate glasses at specific temperatures in the range of 600 to $1300{ }^{\circ} \mathrm{C}$. The effects of $\mathrm{Na}_{2} \mathrm{O}, \mathrm{K}_{2} \mathrm{O}, \mathrm{CaO}, \mathrm{MgO}_{2} \mathrm{Al}_{2} \mathrm{O}_{3}$ and their interactions are evaluated. The influence of minor amounts of $\mathrm{BaO}, \mathrm{B}_{2} \mathrm{O}_{3}, \mathrm{Li}_{2} \mathrm{O}$, and $\mathrm{F}_{2}$, in the temperature range of 700 to $1300{ }^{\circ} \mathrm{C}$, is estimated.
\end{abstract}

Key words: Composition; Fulcher equation; glasses; soda-lime glasses; viscosity.

\section{Introduction}

In his review of the subject of the viscosity of glass, Morey [1] ${ }^{1}$ points out that this property is of practical importance in all stages of the manufacturing process, particularly with the development and use of automatic glass forming machinery. The glass supply should not only be of constant viscosity, but its viscosity-temperature relationship should be suitable for the forming process and the rate of working. Therefore, he continues, the knowledge of the relation between composition and viscosity and between temperature and viscosity is a matter of importance in glass manufacturing. Numerous investigations of this property, reported in the literature, attest to the interest in the viscosity of glasses. Several of these studies were undertaken to develop an understanding of the nature of glass in the molten state. The sole purpose of many others was to determine the effects of composition and temperature on the viscosities of the glasses studied. Titles of the reports of a number of these investigations are listed under section 8 .

The purpose of the investigation reported here is to develop a method for predicting viscosity-temperature relationships from the compositions of silicate glasses of the "soda-lime" type commonly used in the manufacture of glass containers, sheet, and tableware. This investigation is not the first of its kind. The results of previously published studies $[2,3,4,5,6,7$, $8]$ are generally inadequate in predicting the viscosities of simple alkali-silica glasses or fail to indicate the effects on viscosity of interactions between the components in more complex glasses.

${ }^{*}$ Research Associate from the Glass Container Manufacturers Institute, Inc., at the National Bureau of Standards 1972-73. Present address: 317 East Washington, Street Dunkirk, Indiana 47336.

${ }^{1}$ Figures in brackets indicate the literature references at the end of this report.
A reliable prediction of glass viscosity is of value because the measurement of the viscosity of a glass at a number of elevated temperatures requires relatively expensive equipment, care, and effort. The glass for the determination has to be melted and homogenized and it should be chemically analyzed. On the other hand, a predicted glass viscosity may be calculated from the results of a chemical analysis, an analysis calculated from raw materials in the batch, or from a hypothetical glass composition.

Prediction of the viscosity-temperature relationship is of increased value if it is necessary to change the composition of a glass being used in a production operation. It may be possible, through prediction, to make the needed change and still maintain the viscous properties characteristic of the glass formerly produced by making compensating changes in glass composition. If such compensation is not possible, the glass technologist will know, by calculation, how the viscous properties have changed and may observe the effect on the process and product.

\section{Procedures}

All data used in this investigation were taken from published literature. Viscosity is expressed as $\log _{10}$ poise $(P)$. Temperature is given in degrees Celsius $\left({ }^{\circ} \mathrm{C}\right)$.

Discrepancies were found, as anticipated, between the results reported by different authors and laboratories. Results published by Lillie $[9,10]$, the OwensIllinois Research Laboratories [11], Poole [12], and Poole and Gensamer [5] were arbitrarily chosen as standards for evaluating the results from other sources.

Interpolation and extrapolation were used to obtain viscosity values corresponding to $600,700,800,900$, $1000,1100,1200$, and $1300{ }^{\circ} \mathrm{C}$ for each glass composi- 
tion of interest. The Fulcher equation [13] was used for this purpose. It is

$$
\log _{10} \text { viscosity }=A+\frac{B}{T-T_{0}}
$$

in which $T$ is the temperature and $A$ (usually negative), $B$, and $T_{0}$ are constants characteristic of a specific glass composition. The constants were evaluated by least squares [14] treatment of the published viscositytemperature data. $T_{0}$ of eq (1) was found to $1{ }^{\circ} \mathrm{C}$ by iteration. The algebraic equivalent of eq (1),

$$
T=T_{0}+\frac{B}{\log _{10} \text { visc. }-A}
$$

was used alternately to evaluate the constants. $A$ was found by iteration to the nearest $0.01 \log _{10} \mathrm{P}$.

The viscosity values calculated for each temperature level were related to the weight percent composition of the corresponding glasses. Compositions were expressed as functions of the weight percent of components which replace silica in the glass. The development of the empirical equation for calculating viscosity from composition required experimentation in methods of expressing composition and methods of expressing apparent interactions between components. The experimentation advanced from the consideration of two-component alkali-silica glasses to the eventual evaluation of six-component glasses made up of ingredients likely to be found in major amounts in commercial glasses. These ingredients are $\mathrm{Na}_{2} \mathrm{O}$, $\mathrm{K}_{2} \mathrm{O}, \mathrm{CaO}, \mathrm{MgO}, \mathrm{Al}_{2} \mathrm{O}_{3}$, and $\mathrm{SiO}_{2}$. The effects of the minor ingredients $\mathrm{BaO}, \mathrm{B}_{2} \mathrm{O}_{3}, \mathrm{Li}_{2} \mathrm{O}$, and $\mathrm{F}_{2}$ were estimated from the differences between the observed viscosities and viscosities calculated on the basis of the major ingredients present. Two-component interactions which seemed to be of significance were evaluated. No attempt was made to evaluate possible three (or more)-component interactions. Standard least-squares regression procedures were used in making the calculations.

\section{Results}

The empirical equation developed in this investigation to relate the viscosity of a "soda-lime"-silica glass at a specific temperature to its composition is

$$
\begin{aligned}
& \log _{10} \text { poise }=b_{1}+b_{2} \cdot \% \mathrm{Na}_{2} \mathrm{O}+b_{3} \cdot \% \mathrm{~K}_{2} \mathrm{O}+b_{4} \cdot \% \mathrm{CaO} \\
& +b_{5} \cdot \% \mathrm{MgO}+b_{6} \cdot \% \mathrm{Al}_{2} \mathrm{O}_{3}+b_{7} \cdot \sqrt{\mathrm{Na}_{2} \mathrm{~K}_{2} \mathrm{O}_{2}}{ }^{2} \\
& +b_{8} \cdot \% \mathrm{Na}_{2} \mathrm{O} \cdot \% \mathrm{CaO}+b_{9} \cdot \% \mathrm{Na}_{2} \mathrm{O} \cdot \% \mathrm{MgO} \\
& +b_{10} \cdot \% \mathrm{~K}_{2} \mathrm{O} \cdot \% \mathrm{CaO}+b_{11} \cdot \% \mathrm{~K}_{2} \mathrm{O} \cdot \% \mathrm{MgO} \\
& +b_{12} \cdot \% \mathrm{CaO} \cdot \% \mathrm{MgO}+b_{13} \cdot(\% \mathrm{CaO})^{2}+b_{14} \\
& \cdot(\% \mathrm{MgO})^{2}+. . b_{n} \cdot \% N
\end{aligned}
$$

${ }^{2}$ This term represents the amount of the hypothetical equimolecular $\mathrm{Na}_{2} \mathrm{O} \cdot \mathrm{K}_{2} \mathrm{O}$ which could be formed in the glass. It is usually a function of the amount of potash. The amount of soda present could control the amount of the compound theoretically formed in high potash-low soda glasses. The mathematical form provides for a relatively greater effect with low amounts of the second alkali present diminishing effect as the second alkali is increased, and $\mathrm{maximum}$ effect with the two alkalies present in equimolecular concentraincreased where $N$ represents minor ingredients and their interactions.

A summary of components, ranges of composition and data sources for the glasses used in the calculations will be found in appendix A. Appendix B gives an illustrative calculation of viscosity using the predictive factors.

It is to be noted that the constants representing the effects of weight percent component replacing silica are expressed in units of 10 weight percent. This is done to reduce the numerical magnitudes of the products representing interactions and of the second power effects. A soda content of 15.5 percent is thus denoted as 1.55 for purposes of calculation.

The effects on glass viscosity of phosphorous pentoxide [32], zinc oxide [33], strontium oxide [34], and iron oxide [35] may be estimated from published data.

\section{Discussion of Procedures}

The Fulcher equation (eq (1)) is commonly used to express the glass viscosity-temperature relationship. It has limitations. Macedo and Napolitano [15] comment that, in general, if the data are limited to viscosity values between $10^{2}$ and $10^{12}$ a good fit can be obtained to the Fulcher equation. A more serious practical problem arises if the equation is used for extrapolation. If the equation is carefully fitted to high temperature data, it will not reliably predict values at lower temperatures, and the reverse, even though the viscosities are in the range of $10^{2}-10^{12}$. This difficulty may be a consequence of the nature of the viscosity-temperature relationship. Plumat $[16,17]$ argues that the glass viscosity-temperature curve is made up of intersecting curved segments. He illustrates his contention by plotting log viscosity versus reciprocal absolute temperature to show the presence of (nearly) linear segments. The usual viscosity determination has too few data points to illustrate Plumat's concept, but there are three reports $[18,19,20]$ which have sufficient determinations for this purpose. It appears, then, that the values predicted by extrapolation could depend on the positions of the measured data points within the several segments of the viscosity-temperature curve to which the equation is fitted. In preparing data for this investigation it was not always possible to avoid extrapolation; however, extended extrapolation was not needed.

The effect of composition on viscosity at constant temperature is analyzed in this study. However, earlier investigators have evaluated the effect of composition on temperatures corresponding to constant viscosity values. This concept offers a direct approach to the practical problem of the effect of composition change on the glass manufacturing process. The practical interest is in temperatures associated with recognized viscosity levels characteristic of the stages in the manufacturing process. More specifically, the interest is in the temperature change or heat removal needed to advance from one stage to the next. The temperatures of interest can be calculated by use of the 
TABLE 1. The effect of replacement of $10 \mathrm{wt}$. \% silica by other components on the $\log _{10}$ viscosity of glasses at $600-1300{ }^{\circ} \mathrm{C}$

\begin{tabular}{|c|c|c|c|c|c|c|c|c|c|}
\hline \multirow{2}{*}{ Symbol } & \multirow{2}{*}{ Component } & \multicolumn{8}{|c|}{ Factors } \\
\hline & & $600^{\circ}$ & $700^{\circ}$ & $800^{\circ}$ & $900^{\circ}$ & $1000^{\circ}$ & $1100^{\circ}$ & $1200^{\circ}$ & $1300^{\circ}$ \\
\hline $\begin{array}{l}b_{1} \\
b_{2} \\
b_{3} \\
b_{4} \\
b_{5} \\
b_{6} \\
b_{7} \\
b_{8} \\
b_{9} \\
b_{10} \\
b_{11} \\
b_{12} \\
b_{13} \\
b_{14}\end{array}$ & $\begin{array}{l}\text { Intercept } \\
\mathrm{Na}_{2} \mathrm{O} \\
\mathrm{K}_{2} \mathrm{O} \\
\mathrm{CaO} \\
\mathrm{MgO} \\
\mathrm{Al}_{2} \mathrm{O}_{3} \\
\sqrt{\mathrm{Na}_{2} \mathrm{~K}_{2} \mathrm{O}_{2}}{ }^{1} \\
\mathrm{Na}_{2} \mathrm{O} \cdot \mathrm{CaO} \\
\mathrm{Na}_{2} \mathrm{O} \cdot \mathrm{MgO} \\
\mathrm{K}_{2} \mathrm{O} \cdot \mathrm{CaO} \\
\mathrm{K}_{2} \mathrm{O} \cdot \mathrm{MgO} \\
\mathrm{CaO} \cdot \mathrm{MgO} \\
(\mathrm{CaO})^{2} \\
(\mathrm{MgO})^{2}\end{array}$ & $\begin{array}{r}11.7404 \\
-1.4149 \\
-0.8700 \\
3.4391 \\
1.5560 \\
1.3377 \\
-0.5996 \\
-1.1861 \\
-1.0317 \\
-0.3239 \\
-0.4098 \\
-1.2973 \\
-0.2576 \\
1.2377\end{array}$ & $\begin{array}{r}8.9040 \\
-0.9424 \\
-0.6498 \\
2.0773 \\
3.3705 \\
0.9293 \\
-0.1548 \\
-0.9619 \\
-1.2709 \\
-0.4349 \\
-0.6068 \\
-1.7221 \\
-0.1791 \\
-0.3515\end{array}$ & $\begin{array}{r}7.2752 \\
-0.8101 \\
-0.4712 \\
1.4369 \\
3.0888 \\
0.6552 \\
-0.1052 \\
-0.7368 \\
-1.2973 \\
-0.3556 \\
-0.5452 \\
-1.3761 \\
-0.2320 \\
-0.4843\end{array}$ & $\begin{array}{r}6.1155 \\
-0.7182 \\
-0.3781 \\
1.0329 \\
2.5948 \\
0.4982 \\
-0.0690 \\
-0.5912 \\
-1.1189 \\
-0.3158 \\
-0.3995 \\
-1.1431 \\
-0.2400 \\
-0.5193\end{array}$ & $\begin{array}{r}5.2559 \\
-0.6535 \\
-0.3336 \\
0.7104 \\
2.1023 \\
0.3896 \\
-0.0323 \\
-0.4816 \\
-0.8889 \\
-0.2923 \\
-0.2462 \\
-0.9721 \\
-0.2013 \\
-0.5366\end{array}$ & $\begin{array}{r}4.5912 \\
-0.6051 \\
-0.3152 \\
0.5395 \\
1.5678 \\
0.3345 \\
-0.0138 \\
-0.4076 \\
-0.6438 \\
-0.2708 \\
-0.0774 \\
-0.8381 \\
-0.2164 \\
-0.4865\end{array}$ & $\begin{array}{r}4.0693 \\
-0.5700 \\
-0.3143 \\
0.3738 \\
1.1125 \\
0.2880 \\
0.0072 \\
-0.3447 \\
-0.4180 \\
-0.2510 \\
0.0669 \\
-0.7307 \\
-0.1995 \\
-0.4540\end{array}$ & $\begin{array}{r}3.6486 \\
-0.5436 \\
-0.3235 \\
0.2385 \\
0.7012 \\
0.2539 \\
0.0260 \\
-0.2936 \\
-0.2089 \\
-0.2330 \\
0.1992 \\
-0.6417 \\
-0.1817 \\
-0.4204\end{array}$ \\
\hline \multicolumn{2}{|c|}{ No. of Glasses ${ }^{2}$} & 72 & 77 & 77 & 77 & 77 & 77 & 77 & 77 \\
\hline \multicolumn{2}{|c|}{ Std. Error of Est. ${ }^{3}$} & 0.1627 & 0.0568 & 0.0462 & 0.0417 & 0.0370 & 0.0327 & 0.0308 & 0.0315 \\
\hline & $\begin{array}{l}\mathrm{BaO} \cdot \mathrm{RO}^{4} \\
\mathrm{Li}_{2} \mathrm{O} \\
\mathrm{Li}_{2} \mathrm{O} \cdot \mathrm{RO}^{5} \\
\mathrm{~B}_{2} \mathrm{O}_{3} \\
\mathrm{~B}_{2} \mathrm{O}_{3} \cdot \mathrm{RO}^{5} \\
\mathrm{~F}_{2}\end{array}$ & & $\begin{array}{r}-0.771 \\
-2.602 \\
-3.516 \\
0.467 \\
-1.075 \\
-4.795\end{array}$ & $\begin{array}{l}-0.650 \\
-1.952 \\
-2.728 \\
-0.446 \\
-0.591 \\
-3.133\end{array}$ & $\begin{array}{l}-0.548 \\
-1.557 \\
-2.160 \\
-0.795 \\
-0.333 \\
-2.284\end{array}$ & $\begin{array}{l}-0.476 \\
-1.318 \\
-1.709 \\
-0.925 \\
-0.169 \\
-1.812\end{array}$ & $\begin{array}{l}-0.418 \\
-1.175 \\
-1.336 \\
-0.984 \\
-0.031 \\
-1.547\end{array}$ & $\begin{array}{r}-0.379 \\
-1.101 \\
-1.006 \\
-0.885 \\
0.050 \\
-1.390\end{array}$ & $\begin{array}{r}-0.333 \\
-1.071 \\
-0.724 \\
-0.754 \\
0.101 \\
-1.303\end{array}$ \\
\hline
\end{tabular}

${ }^{1}$ The amount of the equimolecular compound which theoretically could be formed from the $\mathrm{Na}_{2} \mathrm{O}$ and $\mathrm{K}_{2} \mathrm{O}$ present.

2 The number of glass compositions, i.e., observations, used in the regression calculations of the factors.

$3 \sqrt{\text { Total of variances between calculated and observed results }}$

$\sqrt{\text { Degrees of freedom }}$

${ }^{4}$ Alkaline earth oxides, "RO", excluding BaO.

${ }^{5}$ Alkaline earth oxides including $\mathrm{BaO}$.

factors given in table 1 as outlined in appendix B.

The two propositions: (1) viscosity-composition at constant temperature and (2) temperature-composition at constant viscosity are examined in figures 1 and 2. Figure 1 illustrates the effect of composition on the calculated viscosities of soda-silica and potash-silica glasses at three temperatures. Figure 2 shows the effect of composition on temperatures corresponding to three viscosity levels.

If a linear analysis of the relationship between temperature and composition at constant viscosity (fig. 2) is assumed then constraints arise in the choice of constants for the Fulcher Equation when varying composition. This approach would greatly limit the usefulness of the Fulcher Equation and of the constants, $b_{i}$, in the empirical relation between concentrations of component oxides and viscosity (sec. 3 ). The data in figure 2 is insufficient to suggest an appropriate nonlinear relationship, therefore, the approach relating viscosity to composition by a linear function and viscosity to temperature by the Fulcher equation are chosen instead.

Since glass compositions are expressed in terms of weight percent, it is more convenient to relate viscosity to composition expressed in this way than it is to relate viscosity to composition expressed as molecular percentage or ratios of components. Weight percent is based on a unit weight of material. Molecular percent or ratio are based on neither weight nor volume.
VISCOSITIES AT CONSTANT TEMPERATURES

SODA-AND POTASH-SILICA GLASSES

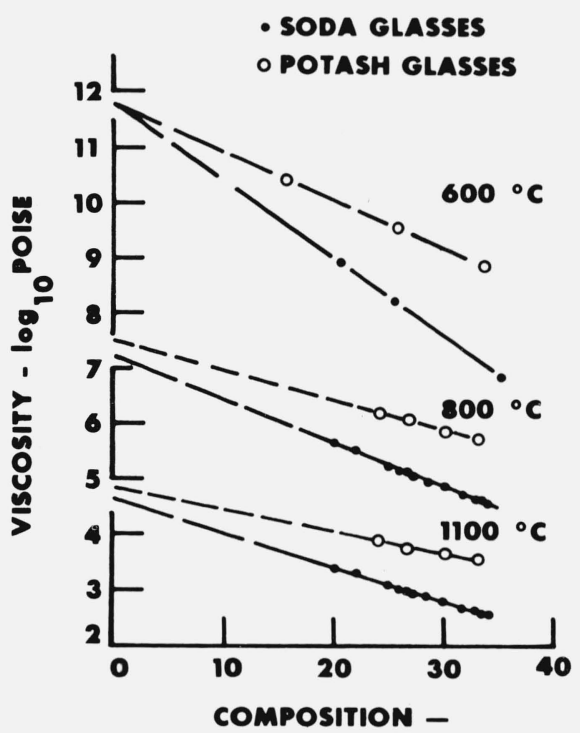

WT. \% ALKALI OXIDE REPLACING SILICA

Figure 1

Huggins [22] has proposed a method of expressing composition in terms of a unit volume of glass defined 
TEMPERATURE FOR CONSTANT VISCOSITIES

SODA-AND POTASH-SILICA GLASSES

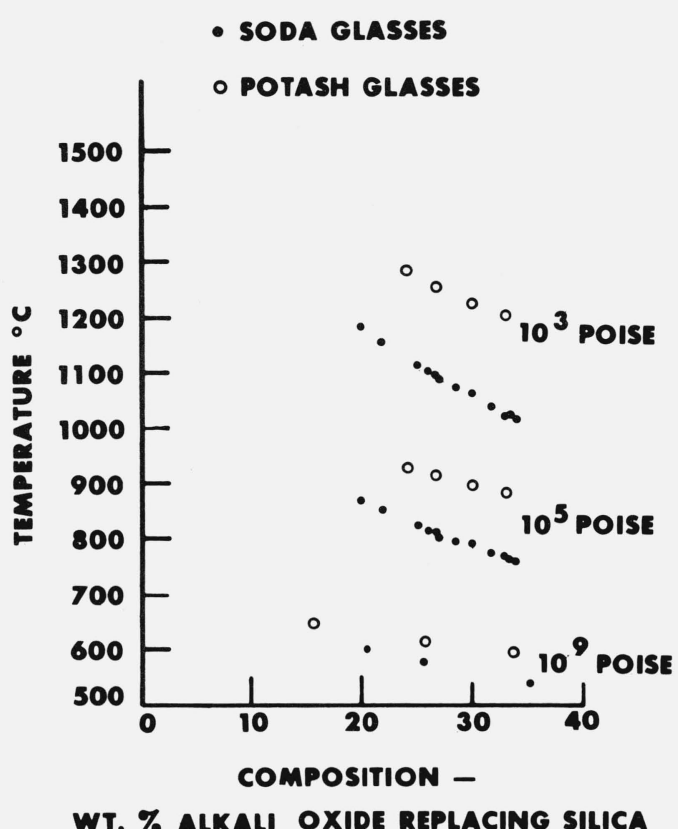

Figure 2

by a fixed number of oxygen atoms. This is not a convenient method. The expression of composition as weight percent seems to be satisfactory for the purposes of the present investigation.

\section{Discussion of Results}

The $\log _{10}$ viscosity-composition relationship for sodasilica glasses appears to be linear in the range of approximately $20-35$ percent soda. There is a distinct change of slope at a soda content near 20 percent, as illustrated in figure 3 . This is probably due to the miscibility gap in the system. The upper end lies near 20 percent soda. The effect of potash in potash-silica glasses seems to be similar as judged from the relatively few viscosity measurements made on low potash glasses.

A number of interactions between components in the glasses are indicated in table 1. Several authors [4, 5, 11, 12, 23] have either implied, referred to, or illustrated some of these. The expression for the soda-potash interaction maximizes the effect at the equimolecular ratio as indicated by Poole [12]. The soda-lime and soda-magnesia interactions are needed to explain the Poole and Gensamer [5] results. It was assumed that there were similar interactions between potash and these two alkaline earth oxides. The limemagnesia interaction is indicated by English [23], is illustrated by Owens-Illinois [11] and is implied by Ochotin [4]. A test calculation failed to indicate a maximum effect of this interaction at the dolomite

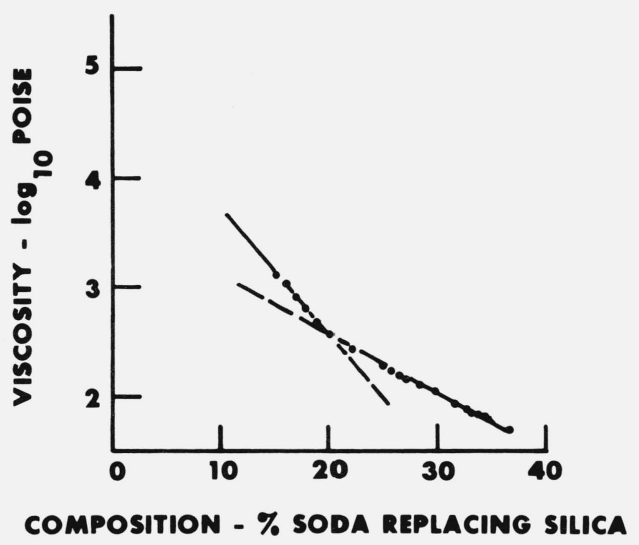

Figure 3

ratio of the oxides. An interaction between lime and alumina illustrated by English [23] could not be confirmed by the results published by Poole and Gensamer [5].

The "Standard Error of Estimate" values (table 1) are large in comparison with the indicated effect of soda, keeping in mind that the soda factors represent the effect of a 10 percent replacement of silica by soda. The magnitude of these "error" values may also be compared with the indicated effect on viscosity of one degree increase of temperature. The latter, listed below, was calculated by differentiation of the Fulcher equation fitted to the mean viscosity values of 77 glasses used in the calculation of the factors of table 1 .

\begin{tabular}{c|c}
\hline \hline Temperature & $-\mathrm{d}(\log$ visc. $) / d T$ \\
\hline${ }^{\circ} \mathrm{C}$ & \\
600 & 0.0346 \\
700 & .0208 \\
800 & .0139 \\
900 & .0099 \\
1000 & .0074 \\
1100 & .0058 \\
1200 & .0046 \\
1300 & .0038 \\
\hline
\end{tabular}

The factors for barium oxide, lithia, and boric oxide show interactions with "RO". These factors were calculated from glass compositions which contained dolomite. The individual effects of lime and magnesia are not evaluated.

The factors were tested by using them to predict the viscosities of six glasses which had not been included in the calculations leading to the results shown in table 1 . The individual glasses are identified by the numbers used in the references from which the data were taken. 
These glasses are:

\begin{tabular}{|c|c|c|c|c|c|c|}
\hline \multirow{2}{*}{$\begin{array}{l}\text { Source } \\
\text { Glass No. }\end{array}$} & \multicolumn{2}{|c|}{$[26]$} & \multicolumn{3}{|c|}{$[27]$} & \multirow{2}{*}{$\frac{[28]}{710}$} \\
\hline & 1 & 2 & 10 & 11 & 330 & \\
\hline $\begin{array}{l}\mathrm{SiO}_{2} \\
\mathrm{Al}_{2} \mathrm{O}_{3} \\
\mathrm{CaO} \\
\mathrm{MgO} \\
\mathrm{BaO} \\
\mathrm{Na}_{2} \mathrm{O} \\
\mathrm{K}_{2} \mathrm{O} \\
\mathrm{B}_{2} \mathrm{O}_{3} \\
\mathrm{Sb}_{2} \mathrm{O}_{3}\end{array}$ & $\begin{array}{c}71.24 \% \\
1.47 \\
10.81 \\
2.92 \\
0.69 \\
12.48 \\
0.39\end{array}$ & $\begin{array}{c}70.80 \% \\
1.82 \\
6.20 \\
4.18 \\
0.78 \\
15.80 \\
0.42\end{array}$ & $\begin{array}{c}70.4 \% \\
2.73 \\
10.6 \\
0.62 \\
0.93 \\
11.9 \\
1.18 \\
0.89\end{array}$ & $\begin{array}{c}71.8 \% \\
2.58 \\
6.01 \\
4.02 \\
0.58 \\
12.6 \\
0.98 \\
0.85\end{array}$ & $\begin{array}{c}69.1 \% \\
1.61 \\
5.60 \\
4.07 \\
0.16 \\
17.7 \\
0.89 \\
0.76\end{array}$ & $\begin{array}{l}70.5 \% \\
11.6\end{array}$ \\
\hline
\end{tabular}

The results of the predictive calculations are given in table 2 .

TABLE 2. Predicted and interpolated viscosities of six glasses

\begin{tabular}{|c|c|c|c|c|c|c|}
\hline \multirow{2}{*}{$\underset{{ }^{\circ} \mathrm{C}}{\text { Temp. }}$} & \multicolumn{2}{|c|}{ Glass No. 1} & \multicolumn{2}{|c|}{ Glass No. 2} & \multicolumn{2}{|c|}{ Glass No. 10} \\
\hline & $\log _{10}$ & Viscosity & $\log _{10}$ & Viscosity & $\log _{10}$ & V iscosity \\
\hline $\begin{array}{r}700 \\
800 \\
900 \\
1000 \\
1100 \\
1200 \\
1300\end{array}$ & $\begin{array}{c}\text { Predict. } \\
8.388 \\
6.475 \\
5.174 \\
4.237 \\
3.515 \\
2.953 \\
2.502\end{array}$ & $\begin{array}{c}\text { Interpol.* } \\
8.382 \\
6.516 \\
5.214 \\
4.260 \\
3.526 \\
2.944 \\
2.473\end{array}$ & $\begin{array}{c}\text { Predict. } \\
7.770 \\
6.069 \\
4.906 \\
4.059 \\
3.417 \\
2.912 \\
2.506\end{array}$ & $\begin{array}{c}\text { Interpol. } \\
7.772 \\
6.113 \\
4.954 \\
4.099 \\
3.441 \\
2.920 \\
2.497\end{array}$ & $\begin{array}{c}\text { Predict. } \\
8.465 \\
6.505 \\
5.196 \\
4.260 \\
3.557 \\
3.017 \\
2.588\end{array}$ & $\begin{array}{c}\text { Interpol. } \\
8.365 \\
6.490 \\
5.208 \\
4.276 \\
3.569 \\
3.013 \\
2.565\end{array}$ \\
\hline 1300 & \multicolumn{2}{|c|}{ Glass No. 11} & \multicolumn{2}{|c|}{ Glass No. 330} & \multicolumn{2}{|c|}{ Glass No. 710} \\
\hline $\begin{array}{r}600 \\
700 \\
800 \\
900 \\
1000 \\
1100 \\
1200 \\
1300\end{array}$ & $\begin{array}{l}8.370 \\
6.557 \\
5.311 \\
4.400 \\
3.708 \\
3.169 \\
2.735\end{array}$ & $\begin{array}{l}8.277 \\
6.526 \\
5.301 \\
4.398 \\
3.703 \\
3.153 \\
2.706\end{array}$ & $\begin{array}{l}7.328 \\
5.670 \\
4.561 \\
3.768 \\
3.174 \\
2.717 \\
2.354\end{array}$ & $\begin{array}{l}7.151 \\
5.640 \\
4.575 \\
3.784 \\
3.173 \\
2.687 \\
2.291\end{array}$ & $\begin{array}{r}11.319 \\
8.219 \\
6.382 \\
5.118 \\
4.201 \\
3.488 \\
2.933 \\
2.484\end{array}$ & $\begin{array}{r}11.057 \\
8.134 \\
6.307 \\
5.056 \\
4.145 \\
3.453 \\
2.909 \\
2.471\end{array}$ \\
\hline
\end{tabular}

*Interpolated from data given in sources.

It is the author's opinion that the differences between predicted and interpolated results shown in table 3 are not serious in view of the several sources of data used in the calculation of the factors and the several sources represented in the tabulation. The results shown for glass No. 710 are of particular interest since this is a standard reference glass for viscosity measurements. It seems reasonable to believe that the consistently higher predicted values may be attributed to the presence of a substantial amount of antimony oxide reported as being in the glass. No predictive factor for the effect of this oxide was developed in this investigation.

In addition to the ranges of composition implied in the summary of appendix A, certain impressions as to applicable limits were formed as the calculations were being made. Table 3 represents a tentative conclusion as to ranges of composition to which the factors may be applied to calculate viscosity. The limits are conservative.

There is no assurance that glass compositions lying within these limits will be free of devitrification or immiscibility effects.

The particular assistance and counsel of G. W. Cleek, L. J. Frolen, A. Napolitano, and G. S. Ross, all of the Institute for Materials Research of the National Bureau of Standards, and of R. A. LeGrand, of the Ball Corporation, is gratefully acknowledged. TABLE 3. Suggested limits of glass composition for viscosity

\begin{tabular}{c|c}
\multicolumn{2}{c}{ prediction } \\
\hline \hline Component & Range-\% \\
\hline $\mathrm{SiO}_{2}$ & $65-80$ \\
$\mathrm{Na}_{2} \mathrm{O}$ & $11-35$ \\
$\mathrm{CaO}$ & $0-14$ \\
$\mathrm{MgO}$ & $0-12$ \\
$\mathrm{CaO}+\mathrm{MgO}$ & $0-16$ \\
$\mathrm{~K}_{2} \mathrm{O}$ & $0-35$ \\
$\mathrm{Al}_{2} \mathrm{O}_{3}$ & $0-8$ \\
$\mathrm{BaO}_{\mathrm{BaO}}$ & $0-5$ \\
$\mathrm{~B}_{3}$ & $0-4$ \\
$\mathrm{Li}_{2} \mathrm{O}$ & $0-4$ \\
$\mathrm{~F}_{2}$ & $0-2$ \\
\hline
\end{tabular}


6. Appendix A. Summary of Glasses Used to Calculate $600{ }^{\circ} \mathrm{C}$ Factors of Table 1

\begin{tabular}{|c|c|c|c|c|c|c|c|}
\hline \multirow{2}{*}{ No. of Glasses } & \multicolumn{6}{|c|}{ Range of composition (percent) } & \multirow{2}{*}{ Source } \\
\hline & $\mathrm{SiO}_{2}$ & $\mathrm{Na}_{2} \mathrm{O}$ & $\mathrm{K}_{2} \mathrm{O}$ & $\mathrm{CaO}$ & $\mathrm{MgO}$ & $\mathrm{Al}_{2} \mathrm{O}_{3}$ & \\
\hline \multicolumn{8}{|c|}{ Two-Component Glasses: } \\
\hline $\begin{array}{l}3 \\
3\end{array}$ & $\begin{array}{l}79.4-64.8 \\
84.3-66.3\end{array}$ & $20.6-35.2$ & $15.7-33.7$ & & & & $\begin{array}{l}{[12]} \\
{[12]}\end{array}$ \\
\hline \multicolumn{8}{|c|}{ Three-Component Glasses: } \\
\hline 6 & $80.7-64.4$ & $4.6-31.3$ & $3.8-14.3$ & & & & {$[12]$} \\
\hline 7 & $77.2-61.5$ & $14.2-24.7$ & & $3.8-14.3$ & & & [5] \\
\hline 8 & $79.1-62.6$ & $15.0-27.8$ & & & $3.1-11.7$ & & [5] \\
\hline 4 & $72.5-65.0$ & $19.8-24.5$ & & & & $5.1-10.2$ & [5] \\
\hline \multicolumn{8}{|c|}{ Four Component Glasses: } \\
\hline $\begin{array}{r}1 \\
10\end{array}$ & $\begin{array}{r}76.1 \\
738-640\end{array}$ & $\begin{array}{r}16.0 \\
128-20.9\end{array}$ & & 4.9 & 3.0 & & {$[5]$} \\
\hline & $73.8-64.0$ & $13.8-20.2$ & & $4.5^{-14.4}$ & & $3.4-10.6$ & \\
\hline \multicolumn{8}{|c|}{ Five-Component Glasses: } \\
\hline 5 & $77.4-66.6$ & $12.1-14.6$ & $0.1-4.4$ & $10.2-12.1$ & & $0.2-7.2$ & [8] \\
\hline 4 & $70.2-67.5$ & $11.9-15.3$ & & $9.8-13.3$ & $0.6-2.3$ & $4.1-7.3$ & [8] \\
\hline 1 & 69.2 & 12.7 & 8.7 & 9.6 & 1.7 & & [8] \\
\hline \multicolumn{8}{|c|}{ Six-Component Glasses: } \\
\hline \multirow{3}{*}{$\begin{array}{c}20 \\
\text { Mean Composi- } \\
\text { tion (percent) }\end{array}$} & $72.0-59.5$ & $10.5-15.0$ & $0.1-8.3$ & $8.2-13.0$ & $0.5-6.7$ & $0.2-6.7$ & {$[8]$} \\
\hline & 69.4 & 16.03 & 3.89 & 6.46 & 1.38 & 2.73 & \\
\hline & ummary & Glasses U & to Calcu & e $700-13$ & ${ }^{\circ} \mathrm{C} \mathrm{Fac}$ & of $\mathrm{Tab}$ & 1 \\
\hline \multicolumn{8}{|c|}{ Two-Component 'Glasses: } \\
\hline $\begin{array}{r}12 \\
5\end{array}$ & $\begin{array}{l}80.0-66.2 \\
76.1-63.4\end{array}$ & $20.0-33.8$ & $23.9-36.6$ & & & & $\begin{array}{c}{[10,21]} \\
{[21]}\end{array}$ \\
\hline \multicolumn{8}{|c|}{ Three-Component Glasses: } \\
\hline 2 & $72.0-70.1$ & $26.8-21.1$ & & $6.8-8.8$ & & & {$[9,29]$} \\
\hline \multicolumn{8}{|c|}{ Four-Component Glasses: } \\
\hline 1 & 71.6 & 19.3 & & 8.9 & & 0.2 & [9] \\
\hline \multicolumn{8}{|c|}{ Five-Component Glasses: } \\
\hline 5 & $77.4-66.6$ & $12.1-14.0$ & $0.1-4.4$ & $10.2-12.1$ & & $0.2-7.2$ & {$[8]$} \\
\hline 23 & $73.8-67.5$ & $11.9-18.0$ & & $0.3-13.3$ & $0.1-11.9$ & $0.1-7.3$ & {$[8,11,30,31,32]$} \\
\hline 1 & 67.2 & 12.7 & 8.7 & 9.6 & 1.7 & & {$[8]$} \\
\hline \multicolumn{8}{|c|}{ Six-Component Glasses: } \\
\hline 28 & $73.4-69.7$ & $10.0-15.9$ & $0.1-8.3$ & $5.9-13.0$ & $0.5-6.7$ & $0.1-6.7$ & {$[8,31,32]$} \\
\hline $\begin{array}{l}\text { Mean Composi- } \\
\text { tion (percent) }\end{array}$ & 70.4 & 15.06 & 3.93 & 6.63 & 2.36 & 1.46 & \\
\hline Other Glasses: & & & $\underline{\mathrm{BaO}}$ & & & & \\
\hline 8 & $73.7-69.1$ & $11.1-13.9$ & $\begin{array}{c}1.0-5.0 \\
\underline{\mathrm{B}_{2}} \underline{\mathrm{O}_{3}}\end{array}$ & $4.2-7.2$ & $2.9-4.9$ & $0.1-0.2$ & {$[33]$} \\
\hline 16 & $74.0-68.6$ & $10.7-16.0$ & $\begin{array}{c}1.0-5.0 \\
\underline{\mathrm{Li}}_{2} \mathrm{O}\end{array}$ & $2.9-7.2$ & $2.1-4.9$ & $0.1-0.3$ & {$[30]$} \\
\hline 6 & $73.6-73.2$ & $8.0-14.0$ & $2.1-6.4$ & $6.1-7.3$ & $4.2-5.0$ & 0.2 & {$[31]$} \\
\hline 2 & $80.6-80.0$ & & $\begin{array}{c}19.4-20.0 \\
\underline{F_{2}}\end{array}$ & & & & \\
\hline 3 & $73.3-71.7$ & $14.4-16.5$ & $1.1-2.0$ & $6.0-7.0$ & $4.2-5.0$ & $0.1-0.2$ & {$[32]$} \\
\hline
\end{tabular}




\section{Appendix B. Calculation of the Viscosity of a Glass and Its Viscosity-Temperature Characteristics}

The method of calculating the viscous properties of a soda-lime glass:

$\begin{array}{lr}\mathrm{SiO}_{2} & 70.61 \% \\ \mathrm{Al}_{2} \mathrm{O}_{3} & 1.47 \\ \mathrm{CaO} & 10.81 \\ \mathrm{MgO} & 2.92 \\ \mathrm{BaO} & 0.69 \\ \mathrm{~B}_{2} \mathrm{O}_{3} & 0.42 \\ \mathrm{Na}_{2} \mathrm{O} & 12.48 \\ \mathrm{~K}_{2} \mathrm{O} & 0.39 \\ \mathrm{Li}_{2} \mathrm{O} & 0.13 \\ \mathrm{~F}_{2} & 0.08\end{array}$

will be illustrated.

The first step in the calculation is the division of the percent values by 10 . Next, calculate the complete list of component values. These component values are then multiplied by the appropriate predictive factors. The total of these products plus the "intercept" value represents the predicted viscosity. The viscosity corresponding to $900{ }^{\circ} \mathrm{C}$. will be calculated.

Calculation of $\log _{10} \mathrm{Viscosity}$ at $900{ }^{\circ} \mathrm{C}$

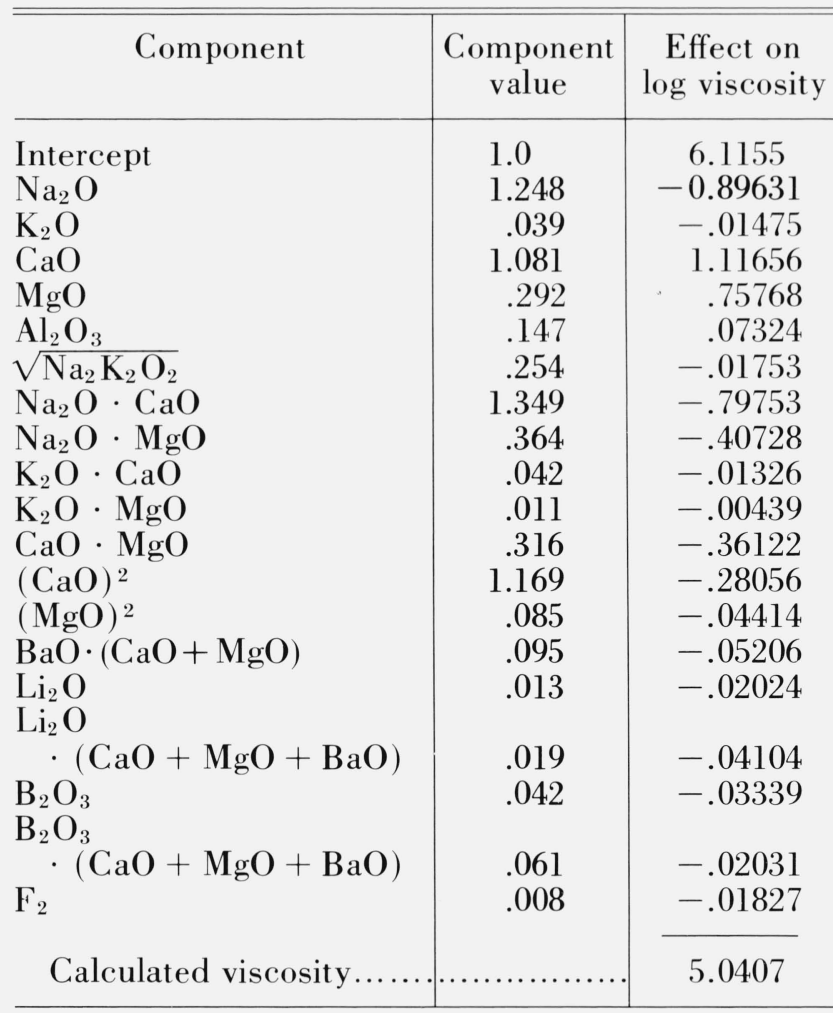

The calculated viscosities for other temperatures are:

$\begin{array}{ll}700^{\circ} & 8.2028 \\ 800 & 6.3175\end{array}$

$\begin{array}{ll}1000 & 4.1234 \\ 1100 & 3.4189 \\ 1200 & 2.8745 \\ 1300 & 2.4382\end{array}$

There are a number of methods which may be used to determine the values of the constants of the Fulcher equation (eq (1)). One of the simpler satisfactory methods is based on the calculated viscosity values for three temperatures. The Fulcher equation is written in the form

$$
\begin{aligned}
\left(-A \cdot T_{0}+B\right)+\left(\log _{10} \mathrm{Visc} .\right) \cdot T_{0} & +T \cdot A \\
& \left.=\mid \log _{10} \mathrm{Visc} .\right) \cdot T
\end{aligned}
$$

Three simultaneous equations representing viscositytemperature characteristics at 700,900 , and $1300{ }^{\circ} \mathrm{C}$., respectively, are written in this form:

$$
\begin{aligned}
& \left(-A \cdot T_{0}+B\right)+8.203 \cdot T_{0}+700 \cdot A=5742.1 \\
& \left(-A \cdot T_{0}+B\right)+5.041 \cdot T_{0}+900 \cdot A=4536.9 \\
& \left(-A \cdot T_{0}+B\right)+2.438 \cdot T_{0}+1300 \cdot A=3169.4
\end{aligned}
$$

The results of the solution of the equations are:

$$
\begin{gathered}
T_{0}=280.3 \\
A=-1.594 \\
B=4111.7 .
\end{gathered}
$$

These constants may be used in the Fulcher equation in the form of eq (1) to calculate viscosities at other temperatures or in the form of eq (2) to calculate temperatures corresponding to specific viscosities such as those of the "working range" [36].

\section{References}

[1] Morey, G. W., The Viscosity of Glass, Ch. 5, The Properties of Glass, 2nd ed., 132-165 (Rheinhold, New York, 1954).

[2] Gehlhoff, G. and Thomas, M., Eigenschaften der Gläser in Abhangekeit von der Zusammansetzung. III Die Viskosität der Gläser. Zeitschr f. Techn. Physik 7, No. 6, 260-278 (1926).

[3] Boow, J., and Turner, W.E.S., The viscosity and working characteristics of glass. Part I-The viscosity of some commercial glasses at temperatures between approximately $500^{\circ}$ and $1400^{\circ}$, Jour. Soc. Gl. Tech. 26, 215-237 (1942).

[4] Ochotin, M. W., Calculation of Viscosity of Commercial Silicate Glasses by the Use of Nomographs, Steklo i Keram. 11, No. 1, 7-11 (1954) Abstracts: Jour. Soc. Gl. Tech 40, No. 12, 169A-170A (1956), Glastech. Ber. 29, No. 6, 253 (1956).

[5] Poole, J. P., and Gensamer, M., Systematic study of effect of oxide constituents on viscosity of silicate glasses at annealing temperatures, Jour. Amer. Ceram. Soc. 32, No. 7, 220-229 (1949).

[6] Allison, R. S., and Turner, W. E. S., Further investigation upon the influence of boric oxide on the rate of melting of the batch, and on the rate of refining and setting of commercial glasses of the soda-lime-silica type, Jour. Soc. Gl. Tech. 38, 297-364 (1954). 
[7] Knapp, O., Berechnung der Viskosität Ternärer Silikat Gläser aus der Zusammensetzung, Glas-Email-Keramo Technik. 18, No. 2, 52-59 (1967).

[8] Lakatos, T., Johansson, L. G., and Simmingsköld, B., Viscosity temperature relations in the glass system $\mathrm{SiO}-\mathrm{Al}_{2} \mathrm{O}_{3}-\mathrm{Na}_{2} \mathrm{O}$ $\mathrm{K}_{2} \mathrm{O}-\mathrm{CaO}-\mathrm{Mgo}$ in the Composition Range of Technical Glass, Glass. Techn. I3, No. 3, 88-95 (1972).

[9] Lillie, H. R., Viscosity of glass between its strain point and melting temperature, Jour. Amer. Ceram. Soc. 14, No. 7, 502-511 (1931).

[10] Lillie, H. R., High temperature viscosities of soda-silica glasses, Jour. Amer. Ceram. Soc. 22, No. 11, 367-374 (1939).

[11] Owens-Illinois Glass Co., General Research Laboratory, Effect of substituting $\mathrm{MgO}$ for $\mathrm{CaO}$ on properties of typical soda-lime glasses, Jour. Amer. Ceram. Soc. 27, No. 8, 221-31 (1944).

[12] Poole, J. P., Low temperature viscosity of alkali silicate glasses, Jour. Amer. Ceram. Soc. 12, No. 7, 230-233 (1949).

[13] Fulcher, G. S., Analysis of recent measurements of the viscosity of glasses, Jour. Amer. Ceram. Soc. 8, No. 6, 339-360 (1925).

[14] Legendre, A. M., Nouvelles Méthodes pour la Détermination des Orbites des Cometes., Appendix: Sur la Méthode des Moindres Quarrés, Paris (1805).

[15] Macedo, P. B., and Napolitano, A., Inadequacies of viscosity theories for $\mathrm{B}_{2} \mathrm{O}_{3}$, Jour. Chem. Phys. 49, No. 4, 1887-1895, (1968).

[16] Plumat, E., Structure du Verre, Traitment Thermique et Viscosité, Sillicates Industriels 21, Nos. 10-11, 391-396, 447-457 (1956).

[17] Plumat, E., Relation entre la Viscosité de Verre et sa Structure en Fonction de la Température et de la Composition, Travaux du IV Congres International du Verre, Paris, July, 1956, Group VI Structure, pp. 299-309, Imprimarie Chaux, Paris (1957).

[18] Napolitano, A., and Hawkins, E. G., Viscosity of a standard soda-lime-silica glass, J. Res. Nat. Bur. Stand. (U.S.) 68A (Phys. and Chem.) No. 5, 439-448 (1964).

[19] Napolitano, A.. and Hawkins, E. G.. Viscosity of a standard lead-silica glass, Nat. Bur. Stand. (U.S.) Misc. Publ. 206-11, 24 pages (1966).

[20] Napolitano, A., and Hawkins, E. G., Viscosity of a standard borosilicate glass, Nat. Bur. Stand. (U.S.) Spec. Publ. 26023, 10 pages (1970).

[21] Shartsis, L., Spinner, S., and Capps, W., Density, expansivity and viscosity of molten alkali silicates, Jour. Amer. Ceram. Soc. 35, No. 6, 155-160 (1952).

[22] Huggins, M. L., Density of silicate glasses as a function of composition, Jour. Optical Soc. Amer. 30, No. 9, 420-430 (1940).
[23] English, S., The Effect of composition on the viscosity of glass. Part III. Some four component glasses, Jour. Soc. Gl. Tech. 9, 83-98 (1925).

[24] Preston, E., The Viscosity of soda-silica glasses at high temperatures and its bearing on their constitution, Jour. Soc. Gl. Tech. 22, No. 90, 45-81 (1938)

[25] Heidtkamp, G. and Endell, K., Ueber die Abhängigkeit der Dichte und det Zahigkeit von temperatur im System $\mathrm{Na}_{2} \mathrm{O}$. $\mathrm{SiO}_{2}$, Glastech. Ber. 14, No. 3, 89-103 (1936).

[26] Babcock, C. L., and McGraw, D. A., Application of glass properties data to forming operations, Glass Ind. 38, No. 3 , 137-146, 148-151, 161 (1957).

[27] Robinson, H. A., and Peterson, C. A., Viscosity of recent container glasses, Jour. Amer. Ceram. Soc. 27, No. 5, 129-138 (1944).

[28] National Bureau of Standards (U.S.), Certificate of Viscosity Values, Standard Sample No. 710, Soda-Lime-Silica Glass, 2pp. Govt. Print. Off. Washington (1962).

[29] Babcock, C. L., Viscosity and Electrical Conductivity of Molten Glasses, Jour. Amer. Ceram. Soc. 1 7, No. 11, 329-342 (1934).

[30] Owens-Illinois Glass Co., General Research Laboratory, Effect of boric oxide on properties of soda-dolomite lime-silica glasses, Jour. Amer. Ceram. Soc. 31, No. 1, 8-14 (1948).

[31] Owens-Illinois Glass Co., General Research and New Development Division, Effect of $\mathrm{K}_{2} \mathrm{O}$ and $\mathrm{Li}_{2} \mathrm{O}$ on properties of sodadolomite lime-silica glasses, Jour. Amer. Ceram. Soc. 33, No. 6, 181-187 (1950).

[32] Owens-Illinois Glass Co., General Research Laboratory, Effect of fluorine and phosphorous pentoxide on properties of sodadolomite lime-silica glass, Jour. Amer. Ceram. Soc. 27, No. 12, 369-372 (1944).

[33] General Research Laboratory, Owens-Illinois Glass Co., Effect of barium and zinc oxide on the properties of sodadolomite lime-silica glasses, Jour. Amer. Ceram. Soc., 25, No. 3, 61-69 (1942).

[34] Owens-Illinois Glass Co., General Research Laboratory, Properties of soda-strontium oxide-alumina-silica glasses, Jour. Amer. Ceram. Soc. 31, No. 1, 1-8 (1948).

[35] Owens-Illinois Glass Company, General Research Laboratory, Effect of iron oxide on properties of soda-dolomite limesilica glass, Jour. Amer. Ceram. Soc. 25, No. 14, 401-408, (1942).

[36] American Society for Testing and Materials, Standard definitions of terms relating to glass and glass products, Designation C $162-71,14 \mathrm{pp}$. Am. Soc. for Testing and Materials, Philadelphia.

(Paper 78A4-829) 